Mykola Sidak

Comenius University in Bratislava

Jan Mazur

Comenius University in Bratislava

\title{
THE INNOVATION OF BUDGETARY FRAMEWORKS OF THE SLOVAK REPUBLIC REFLECTING THE STRENGTHENING OF EUROPEAN REGULATION AND RESPONSIBILITY ${ }^{1}$
}

The recent sovereign debt crisis has pushed the boundaries of acceptable debt within the eurozone and the EU. Several new legal documents create a strengthened budgetary framework of the member states and thus the EU as a whole. As a part of the Six Pack, Council Directive 2011/85/EU on Requirements for Budgetary Frameworks of the Member States, introduced requirements on accounting, statistics, auditing, independent prognosis, medium-term budgetary frameworks and transparency rules. The Slovak Republic has implemented the document and created an enhanced budgetary framework with new fiscal responsibility rules on the constitutional level, a new constitutional fiscal supervisory body and the very first recognition of the rights of future generations in the Slovak Constitution. However, the numerical rules are implemented insufficiently leaving out the deficit rule, the escape clauses do not leave enough space for countercyclical measures and the framework relies more on procedural aspects than on results. It is a step forward, but some changes in its implementation are needed in order to establish a more solid standard of budget responsibility.

1 This article aims to deliver a report on the implementation of Council Directive 2011/85/EU on Requirements for Budgetary Frameworks of the Member States (further as "Directive") into the Slovak legal system. We hold that some of the rules implemented were already present in the legal system and some correlated with the adoption of the Two Pack. We examine the implementing laws in comparison with the Directive. Furthermore, we analyze the existing binding rules, their suitability and potential for improvement. 
In the past 6 years the debt ${ }^{2}$ of the Slovak Republic relative to GDP increased almost twofold, from a pre-crisis $27,9 \%$ of GDP in 2008 to an estimated $54,3 \%$ of GDP in $2013^{3}$.

The debt levels have exceeded the pre-consolidation levels from the early $2000 \mathrm{~s}$. Moreover, it is expected to rise slightly more, to converge at around $56,8 \%$ of GDP and thereafter to start declining. The Slovak Republic has been under the excessive deficit procedure since 2009. The abrupt change in the debt development of the Slovak Republic lead to a swift and rather unique widely supported legislative action in the Slovak political environment, i.e. fast implementation of fiscal rules. A new Constitutional Act No. 493/2011 Col. on Fiscal Responsibility (further as "Constitutional Act") has been enacted (effective as of March 1, 2012). Along with already existing acts on budget rules for public services and regional selfadministration, it has strengthened the budgetary framework of the Slovak Republic.

According to the definition of the budgetary framework as defined in Article 2 of the Directive, the amended budgetary framework of the Slovak Republic has institutional, procedural, rule-based and organizational form. The institutional form is expressed in the existence of the new fiscal surveillance body, the Council for Budget Responsibility (further as "Council"). Procedural form consists of noncompliance procedures described by the Constitutional Act, as well as procedures of composing the annual budgets as expressed by the two major acts on budget rules, the Act No. 523/2004 on Budget Rules of Public Service (further as "act on budget rules of public service") and the Act No. 583/2004 on Budget Rules of the Regional SelfAdministration (further as "act on budget rules of the regional self-administration"). The rule-based approach can be seen in numerical fiscal rules, escape clauses, as well as in transparency and data-related rules.

The Directive calls for establishing "a credible, effective medium-term budgetary framework providing for the adoption of a fiscal planning horizon of at least three years, to ensure that national fiscal planning follows a multiannual fiscal planning perspective" . Its main parts are multiannual budgetary objectives regarding debt, deficit and other summary fiscal indicators consistent with the numerical fiscal rules, projections of expenditure and revenue items on unchanged policies, description of medium-term policies along with their impact on public finances, and assessment of achieving the long-term sustainability of the public finances.

In its Stability Programme of the Slovak Republic for 2013 to 2016 Report of April 2013, ${ }^{5}$ the Ministry of Finance of the Slovak Republic stated that most of the requirements of the Directive had already been implemented. The Directive itself

2 Debt is defined as the Maastricht debt as reported by Eurostat.

3 Eurostat historical data and estimate of the Council for Budget Responsibility. Available online (accessed on March 24 2014): <http://www.rozpoctovarada.sk/svk/rozpocet/200/aktualny-vyvoj-dlhu-sr>.

4 Article 91 of the Directive.

5 Available online (accessed on March 23 2014): <https://www.finance.gov.sk/en/Components/ CategoryDocuments/s_LoadDocument.aspx?categoryld=347\&documentld=462>. 
The innovation of budgetary frameworks of the Slovak Republic reflecting...

consists of several chapters: Chapter II on Accounting and Statistics, Chapter III on Forecasts, Chapter IV on Numerical Fiscal Rules, Chapter V on Medium-term Budgetary Frameworks and Chapter VI on Transparency of General Government Finances and Comprehensive Scope of Budgetary Frameworks. The structure of the Directive logically ties the medium-term budgetary frameworks and rules together, (i) by creating comprehensive and consistent accounting systems along with a timely and regular public availability of fiscal data; (ii) by ensuring that fiscal planning is based on realistic macroeconomic and budgetary forecasts in cooperation with the Commission; (iii) by effectively following the country's specific numerical fiscal rules and rules for non-compliance; (iv) by creating the core medium-term budgetary frameworks consistent with the numerical fiscal rules and based on the macroeconomic and budgetary forecasts; and (v) by ensuring that any measures taken to comply with Chapters II, III and IV, are consistent, transparent and allow for fiscal accountability and public scrutiny.

The implementation of the Directive to Slovak legal regime concerns three major acts, one of which is of constitutional power. Though the Constitution of the Slovak Republic itself deals with the budgetary legal framework only marginally ${ }^{6}$ and basically leaves budgeting to be further adjusted by acts of parliament, the enactment of the Constitutional Act introduced fiscal rules and an independent fiscal surveillance body at the constitutional level. Fiscal rules at the constitutional level present a more suitable option than at regular act level because of their superiority. The Constitutional Act aims to deliver a long-term sustainability of public finances of the Slovak republic. Also, it has the very first constitutional provision in the Slovak legal environment that recognizes the rights of future generations and tries to mitigate the consequences of debt burden on them. However, the mention is only a brief one.

The Constitutional Act can be considered a law containing mixed procedural, institutional and numerical rules. Corbacho and Schwarz recognize four main types of numerical fiscal rules: deficit rules, debt rules, borrowing rules and expenditure rules $^{7}$. The Directive emphasizes the deficit and debt rules according to the Treaty on the Functioning of the European Union (further as "TFEU"). Even though the Constitutional Act contains the numerical rules, it complies with the Directive only partially, because while it sets the debt limit at $50 \%$ of GDP G $^{8}$ it leaves out the deficit rule. The lack of deficit rule is also problematic from the perspective of the

The Constitution states in the Article 58 (1) that the financial management of the republic is governed by the state budget in the form of an act of parliament. Budget proposals are submitted to the parliament by the government. The details and budget rules are left to be further adjusted by the acts. The act on budget cannot be the subject of a referendum.

7 Corbacho, Ana, and Gerd Schwartz. Promoting Fiscal Discipline. Ed. Manmohan S. Kumar and Teresa Ter -Minassian. [Washington, D.C.]: International Monetary Fund, 2007. Print, page 60.

8 The limit is currently set at $60 \%$ of GDP, but will start to decline by one percentage point a year starting in 2018 until the limit sustains on $50 \%$ of GDP, which is to be kept. 
preventive and corrective arm of the Stability and Growth Pact criteria (further as "SGP"), which rely not only on the debt limit but also on deficit levels below $3 \%$ of GDP. Slovakia has been under the excessive deficit procedure since 2009 and while the debt level remains under the $60 \%$, the deficit levels are not obeyed and continue to be a problem. This deficiency of the Constitutional Act was also remarked by the ECB in the Opinion of the ECB of 5 December 2011. ${ }^{9}$ The omission of the deficit rule can be considered as one of the greatest weaknesses of the law.

The debt level set at $50 \%$ of GDP is specifically adjusted 10 percentage points downwards from the SGP to suit the Slovak Republic. This is in line with Articles 5 and 6 of the Directive, which create a space for country specific rules. It is claimed that smaller and more open economies should keep their debts within even stricter limits. ${ }^{10}$ The act contains the consequences and procedures in the event of noncompliance according to Article 61 (c) of the Directive. These are justifications, government proposals and decrease or freeze of the government officials' salaries, expenditure limits and as the most severe of the consequences a vote of confidence, when particular thresholds are breached $(40 \%, 43 \%, 47 \%$ and $50 \%$ respectively).

Another weak point of the Constitutional Act is the fact that the debt limit itself only binds the government to a limit-compliant budget proposal, but does not prevent the National Council (further as "parliament") to adjust government budget proposals above the debt limit. While the Directive confers the responsibility to comply with the debt rules on the member state, the Slovak law keeps the responsibility on the government, not on the parliament, which as a sovereign legislative power enacts the final version of the budget. This emphasis on the procedural side and not on the result side of the debt limit might be problematic, especially when the government has a solid majority of votes in the parliament, which might allow it to effectively bypass the debt limit.

The ECB further states that the provisions for the economic cycle are not implemented satisfactorily and should be changed to go beyond the current escape clauses applicable in the severest of circumstances, which concern the GDP drop of 12 percentage points year-to-year, banking crisis and natural disasters costing the public budgets at least 3\% of GDP collectively, and affects arising from any acts of war. The GDP drop, as set by the Constitutional Act, does not leave much space for counter-cyclicality and might be too austere. Also, the newly established government can implement its own fiscal policies and priorities and is exempted from the strict budget rules (debt levels from $45 \%$ of GDP on) during the first half of its mandate, i.e. for two years, which raises the question of the efficiency and continuity of the debt limit. There is a general lack of business-cycle approach to the numerical fiscal

9 Opinion of the ECB of 5 December 2011 on fiscal responsibility.CON/2011/96, available online (accessed on March 24 2014): <http://www.ecb.europa.eu/ecb/legal/pdf/en_con_2011_96_f_sign.pdf>.

10 As acknowledged in the Explanatory Statement to the Constitutional Act. Available online (accessed on March 24 2014): <http://www.nrsr.sk/web/Default.aspx?sid=zakony/zakon\&MasterlD=3884>. 
The innovation of budgetary frameworks of the Slovak Republic reflecting...

rules, which are very narrow and do not reflect cyclicality, deficit and structural deficit issues.

As previously mentioned, the Constitutional Act established a new fiscal surveillance body, the Council for Budget Responsibility, which has several monitoring, evaluating and controlling competencies. The Council, described as an independent body monitoring and evaluating the economy of the Slovak Republic, consists of elected expert professionals. It issues annual reports on the long-term sustainability of public finances and reports on fiscal responsibility and fiscal transparency, ex officio statements to legislative proposals and other surveillance reports. Though the Council's establishment was based primarily on the Two-Pack, the Council's competencies are also implied in Article 61 (b) of the Directive. Generally, the main purpose of the fiscal councils is to assess the debt position, its trajectory, and relevant budget measures, since the government forecasts generally appear to be way too optimistic. The optimistic deviations seem to be smaller in countries where independent bodies monitored or produced these data. ${ }^{11}$

The Constitutional Act also constitutionally sets forth a 3-year medium-term budget planning for the state budgets, budgets of public administration and local governments' budgets. The 3-year budget planning has been present in the Slovak budget law since the 1995 Act on Budget Rules, which introduced multiannual budget plans. The 1995 act was later replaced by the 2004 acts on budget rules, which sustained the medium-term budget rule. However a novelized principle of continuity of budgets as embedded within the Constitutional Act, also requires that budgets have to evaluate the actual fulfillment of budgets for the two previous years in preparing the budgets for the following years. This new rule fortifies the continuity of budgeting by creating 5-year budget clusters. Only the budget for the current year has binding power, the budgets for the two following years are indicative, but should serve as grounds for the subsequent preparation of the annual budget. ${ }^{12}$ The medium-term budget framework fortifies budgetary objectives for the government by projecting the revenues and expenditures in time. The framework also requires that impacts on the long-term sustainability of the budgeting must be predicted. The 3 -year budgeting rule is further emphasized by the two respective acts on budget rules of public service and regional self-administration.

The public budget must contain additional data according to the Constitutional Act; i.e. a consolidated balance sheet of public administration, debt management strategy, tax expenditures, implicit liabilities and conditioned liabilities, exceptional measures and influences, and data on the management of public corporations. To further extend transparency and public scrutiny the annual report of the Slovak

\footnotetext{
11 The importance and effectiveness of national fiscal frameworks in the EU. ECB Monthly Bulletin February 2013. ECB, 2013. Page 76.

12 Interim Progress Report on the implementation of Council Directive 2011/85/EU on requirements for budgetary frameworks of the Member States. Occasional Papers 128. European Commission. February 2013. Page 14.
} 
Republic must contain, on top of regular data, the data on net wealth of the Slovak Republic, balance sheet of the public administration, evaluation of debt management objectives fulfillment, exceptional measures and influences, and data on the management of public corporations.

Solid accounting systems subject to internal control and independent audits must be in place in order to avoid creative accounting. The Directive sets the rules to publish the fiscal data of the government and social security sub-sectors monthly and of the local government sub-sector quarterly, along with the methodology. These rules are implemented to some extent within the acts on budget rules, as well as in the Ministry of Finance Measure. ${ }^{13}$ Cash-based fiscal data for state budgets are available online on a regular basis, but monthly data for the whole central government sector and social security funds, as well as the quarterly data of local self-administrations, are seen lacking. ${ }^{14}$

The Directive asks for founding the fiscal planning on realistic macroeconomic and budgetary forecasts. The Commission's own data is used as a benchmark to the data gathered by independent bodies established within the member states. Consequently the Constitutional Act established two advisory bodies to the minister of finance; these are the Tax Revenue Forecasts Committee and the Macroeconomic Forecasting Committee. The committees support transparency and provide analyses and prognoses for the budget making process. These analyses are published by the Ministry of Finance and present an important basis for the budgeting of all public bodies. The Council also plays a crucial role in the process by publishing additional reports and data, as well as methodology standards. The main publications of the Council are the annual Report on the Long-Term Sustainability of Public Finances, aiming at forecasting the debt and its growth under the actual policy, and the Report on Compliance with the Fiscal Responsibility and Fiscal Transparency Rules, aiming at monitoring and checking the government's fiscal responsibility performance as well as checking whether the transparency rules are obeyed.

Self-Administration Units are included within the public budget framework and their debt is counted in the overall public debt. This ties their budgets to the state budget. They are also touched by the breach of debt levels of $45 \%$ and $47 \%$ of GDP; in case of breach of the former level units cannot approve a higher budget than the budget for a previous year, and in case of the latter level the units must approve a balanced budget. However, the Constitutional Act forbids any leaks from the debt of self-administration units into the state budget. It clearly separates their finances from those of the state by explicitly affirming that the state does not secure, nor guarantee solvency of the self-administration units. The finances of these units are governed by the "Golden Rule", which imposes a debt limit at $60 \%$ of the current revenue. Local 
The innovation of budgetary frameworks of the Slovak Republic reflecting...

authorities are also constrained by the second rule stating that the sum of the annual installments of the loans cannot exceed $25 \%$ of the revenue for the previous year. However, there are remarks that local authorities might use different assumptions of macroeconomic projections, because of their independence in the budget making process. ${ }^{15}$ Local authorities should use the statistics of the committees associated to the Ministry of Finance. Nonetheless, the act on budget rules of the regional selfadministration penalizes the breach of this rule by a fine imposed by the Ministry of Finance. If the state assigns any new functions to the units, it is obliged to arrange for additional funds.

The Directive introduced enhanced budgetary frameworks into member states. The Slovak Republic has implemented the Directive, though with mixed results. The accounting, statistics, data provision and transparency are implemented generally well and do not pose any serious problems. The accounting standards and statistics are available; the forecasts are produced on a regular basis. Even though the Council has only been in existence for two years, it seems to be fulfilling its constitutional duties thoroughly, on a professional and expert basis and its members are highly respected. Their reports are generally independent and impartially critical to the endeavors of the government. Moreover, the Council often issues additional working papers, commentaries on methodology, statements and other reports. The numerical rules, composition of the escape clauses, and procedural emphasis in the budget proposal process, seem to be the weakest points of the transposition. We conclude that as a first step the Constitutional Act introduces many much-needed and important institutions into Slovak law, but cannot be considered a final product and offers room for improvement. 


\section{INNOWACYJNOŚĆ RAM BUDŻETOWYCH REPUBLIKI SŁOWACKIEJ ODZWIERCIEDLAJĄCA WZMOCNIENIE EUROPEJSKIEJ REGULACJI I ODPOWIEDZIALNOŚCI}

Artykuł ma na celu przedstawienie raportu z wdrożenia Dyrektywy Rady 2011/85/UE w sprawie wymogów dla ram budżetowych państw członkowskich do słowackiego systemu prawnego. Zdaniem autorów, niektóre $\mathrm{z}$ wdrożonych reguł znajdowały się już w systemie prawnym, a niektóre korelowały z przyjęciem „dwupaku". W artykule ocenie poddano przyjęte regulacje w porównaniu z Dyrektywą oraz przeanalizowano obecnie obowiązujące reguły, ich stosowność i możliwości ulepszenia.

Słowa kluczowe: kryzys na rynku obligacji skarbowych, ramy budżetowe, reguły fiskalne, rada fiskalna

Keywords: sovereign debt crisis, budgetary frameworks, fiscal responsibility rules, fiscal responsibility board 